weights approximating to $35,000 \times 1,2,4$ or 8 . Many of these under conditions of varying $p \mathrm{H}$ can break up reversibly into segments which are simple submultiples of the original molecular weight. It is also interesting to notice that Bergmann and Niemann (since the above prediction) state that the chemical analysis of egg albumin enables them to deduce that this molecule consists of exactly 288 residues $(J$. Biol. Chem., 118, 301 ; 1937).

A series of models based on the truncated tetrahedron formed from the cyclol fabric and simple polymers of this, thus accounts satisfactorily for the type of molecular weight series found in some 'globular' proteins, namely, simple multiples of a basic unit of 35,000 .

\section{The Problem of Leisure}

$\mathrm{W}^{\mathrm{n}}$ have not infrequently insisted upon the problem of leisure as one of growing importance, and have emphasized the inevitable effects of the application of science to industrial processeseffects which have been put under the heading of 'technological unemployment'. As the machine lessens the volume of toil required from men and women, our social organization must be adapted to give the new services which will be demanded of it. Already the move towards a reduction in working hours is apparent and must bring with it a corresponding increase in the hours of leisure. How will that leisure be used?

The widespread interest in the possible answers to that question was shown on November 18 when more than two hundred bodies were represented at a conference arranged by the National Institute of Industrial Psychology and the British Institute of Adult Education. The problem of leisure was the problem which attracted that very large audience, and it was finally decided to set up a committee representative of bodies willing to co-operate in the carrying out of what might be called our first survey of leisure. It will consist in the first place of an investigation of the opportunities for leisure, for, clearly, any such survey will fail in its purpose if it neglect factors such as housing conditions, transport facilities, the extent to which poverty debars from participation in recreation, and other similar considerations.

The purpose of any report which may be drawn up as a result of the investigation will not be to interfere with or supplant the work of bodies already engaged in work affecting leisure activities, but to assist them.

The survey will be on broad lines and will recognize that, while many leisure pursuits require organization, resentment would arise from anything suggestive of coercion, patronage or intrusion on individual privacy.

The present suggestion is that the investigators should base their report upon a first-hand examination of the facts in certain districts which would be selected so far as possible as being typical of prevalent conditions. The following list of districts has been compiled as one where investigations would doubtless be most profitable: a town of varied districts where the factories, dwellings and recreational facilities are within easy reach of one another ; a district where the workers' dwellings and their recreational facilities are distant from their work ; a developing district where the conditions of work and leisure have been planned, but where the population has grown up without local civic conditions; a developing, but unplanned, district; a district where varied industries are scattered amid rural surroundings; and a popular holiday resort, with special reference to the increasing extension of the holiday season beyond the summer months. The increase of holidays with pay, the raising of the age of entry, and the lowering of the age of exit, from industry and the incidence of shift work are all factors which must be taken into consideration as the investigation proceeds. Duplication of effort will be avoided and investigators will be asked to distinguish carefully between the collection of fact, the collection of opinion and their own conclusions.

\section{Science News a Century Ago}

\section{Anniversary Meeting of the Royal Society}

AT the anniversary meeting of the Royal Society on November 30, 1837, the president, H.R.H. the Duke of Sussex, being prevented from attending by illness, his address was read by Francis Baily. In the report of the Council for the year, it was said: "The principal business of public interest which has occupied the attention of the Council relates to the extension of accurate magnetical and meteorological observations in different parts of the world.

"A communication having been made by Lieut. William Denison, of the Royal Engineers, of a proposal from General Mulcaster, Inspector-General of Fortifications, that the officers of engineers generally should be employed, under the direction of the Royal Society, in promoting the advancement of science, by carrying on connected series of observations relating to Natural History, Meteorology, Magnetism and other branches of physical science, and suggesting an application to Government for a grant of funds necessary for effecting so desirable an object; a Committee was appointed to consider the proposed measure, and of the means to carry into effect the recommendations contained in the letter of Baron Von Humboldt addressed in April last to the President. Conformably with the report the Council fixed on the ten following places, namely, Gibraltar, Corfu, Ceylon, Hobart Town, Jamaica, Barbados, Newfoundland, Toronto, Bagdad and the Cape of Good Hope as being the most eligible for carrying on magnetic observations . . . these places being permanent stations where officers of engineers and clerks are always to be found." A grant of $£ 500$ for instruments was afterwards obtained from the Government.

\section{Award of Two Copley Medals}

THE report of the Council also referred to the award of the various medals, two Copley Medals being awarded on this occasion, one to A. C. Becquerel and the other to J.F. Daniell. The award to Becquerel was "particularly for the production of crystals of Metallic Sulphurets and of Sulphur; by the longcontinued action of electricity of very low tension. In the memoirs particularly referred to by the Council he has especially in view to explain, by the agency of electricity of very low tension, continued for an indefinite time, the occurrence of erystalised substances in mineral veins. By his work $\mathrm{Mr}$. 
Becquerel has thus opened up a new field for inquiry and discovery, in which he has himself gathered the first fruits, but which still offers to future labourers the prospect of an abundant harvest of knowledge as regards both the recomposition of crystalised bodies and also the processes which may have been employed by nature in the production of such bodies in the mineral kingdom."

Antoine César Becquerel was born on March 7, 1788 and died on January 18, 1878. After passing through the École Polytechnique, he served in the French army for a short time but soon quitted the service and devoted himself to scientific research. $\mathrm{He}$ was one of the founders of electro-chemistry. $\mathrm{He}$ was admitted a member of the Paris Academy of Sciences in 1829. Becquerel was appointed to the chair of physics in the Musée d'histoire naturelle in 1837 and this post he held until his death. He was succeeded in the chair first by his son Alexander Edmond Becquerel (1820-91), and then by his grandson Antoine-Henri Becquerel (1832-1908), the discoverer of radioactivity. A statue of Antoine César Becquerel was unveiled at his birthplace, Châtillon-sur-Loing (Loiret), in 1882.

\section{Level of the Caspian Sea}

Is a letter written from Dorpat on December 1, 1837, to Alexander von Humboldt, Friedrich von Struve, the famous astronomer, referring to the geodetical operations carried out by the order of the Emperor of Russia to determine the level of the Caspian Sea, said, "Our travellers G. von Fuss, Sabler and Sawitsch happily completed their laborious task on the 23rd of October. I have just received the reports and a copy of the journals from the village of Tschernoi-Rynof, near the station of Kolpitschja (on the road from Kisljar to Astrachan) dispatched on the 31st of October (N.S.). The rapid progress of the operations made it impossible to keep up the calculations at the same pace. Our travellers, however, have gone through the whole and are able by a preliminary calculation to state at once the following result as very near the truth:--that the Caspian Sea is really considerably lower than the Euxine: viz., 101.2 Russian $=94.9$ Paris feet. This preliminary result is warranted to be correct within five feet" (Athenoum, Dec. 23, 1837).

\section{University Events}

Birmingham.-At a special meeting of the Court of Governors held on November 18 the pro-chancellor (Mr. Walter Barrow) presiding, the resignation of the vice-chancellor (Sir Charles Grant Robertson) was accepted, the resignation to take effect on September 30,1938 . The appointment of the vice-chancellor has hitherto been made by the Crown and no age limit was attached, but by an alteration of the statutes (in 1927), future appointments were to be made by the Court and an age limit of sixty-five years was fixed. The pro-chancellor explained that, on approaching this age, Sir Charles voluntarily placed the continuance of his appointment in the hands of the Council, who expressed the wish that he should remain in office until the completion of the new Central Hospital and Medical School, which owed so much to his vision and patient work. As it is expected that both buildings will be finished by next summer,
Sir Charles desired that he should retire on September 30 next, when he would have reached the age of sixty-nine years.

The Court then proceeded, for the first time, to elect a new vice-chancellor, and the pro-chancellor proposed, on behalf of the Council, the name of Dr. Raymond E. Priestley, giving an outline of his remarkable achievements. The proposition was seconded by the vice-principal (Prof. J. G. Smith) and warmly supported by Sir Gilbert Barling and (from personal knowledge) by Mr. J. H. Reynolds, Prof. M. L. Oliphant and Prof. Lees. The Court unanimously elected Dr. Priestley.

After the meeting of the Court a portrait of Sir Charles Grant Robertson (by Mr. James Gunn), presented to the University by 225 subscribers, was unveiled in the Great Hall by the wife of the prochancellor.

Earlier in the afternoon Mr. T. E. Harvey, M.P. (Combined Universities), had formally opened St. Francis' Hall, a chapel given to the University by Mr. and Mrs. Edward Cadbury for the use of the undergraduates.

CAmbridge.-A research studentship at Emmanuel College will be awarded in July 1938. Preference will be given to Candidates who have already completed one but not more than two years of research. The studentship has a maximum annual value of $£ 150$, is awarded and normally held for two years, but may be renewed for a third. The studentship is not tenable by a woman or by a member of the University of Cambridge. Further information can be obtained from the Master, Emmanuel College, Cambridge.

An appointment to a research studentship at Christ's College will be made at the end of July 1938. Candidates must be men who will have graduated before October 1, 1938, at some university other than Cambridge, and who have not commenced residence in Cambridge at the time of election. The studentship will be normally held for two years, but it may be prolonged for a third year in exceptional circumstances. It is of annual value not exceeding $£ 200$. Further information can be obtained from the Master, Christ's College, Cambridge.

LeEds.-Dr. J. W. Orr, lecturer in experimental pathology, was elected to the post of reader. Dr. Orr is also assistant director of cancer research.

The following appointments have been made: Dr. H. G. Garland as clinical lecturer in medicine and honorary demonstrator in medical pathology; Dr. J. A. Price as honorary demonstrator in medicine; N. Lissimore as honorary demonstrator in pathology; F. R. W. Hemsley and I. J. Keidan as honorary demonstrators in anatomy; Miss Florence O. Bell as research assistant in textile physics.

London.-Prof. A. J. Allmand has been appointed as from August 1, 1938, to the Daniell chair of chemistry tenable at King's College. Since 1919 he has held the University chair of chemistry at that College.

The following have been appointed University readers: Dr. L. P. Garrod (St. Bartholomew's Hospital Medical College) in bacteriology; Dr. C. F. Goodeve (University College) in chemistry; C. W. Dannatt (Imperial College-Royal School of Mines) in metallurgy; Dr. H. J. T. Ellingham (Imperial College of Science and Technology) in physical chemistry. 